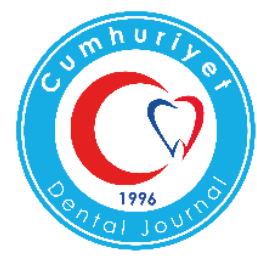

\title{
THE EFFICACY OF FOUR CAVITY DISINFECTANT SOLUTIONS AND TWO DIFFERENT TYPES OF LASER ON THE MICRO-SHEAR BOND STRENGTH OF DENTIN ADHESIVES
}

\author{
Dört Kavite Dezenfektan Solüsyonunun Ve İki Farklı Lazer Sisteminin Dentin \\ Adezivlerin Mikro Makaslama Bağlanma Dayanımı Üzerine Etkinliği
}

Oguzhan ALICI, Ihsan HUBBEZOGLU

\begin{abstract}
Makale Kodu/Article Code : 395212
Makale Gönderilme Tarihi $\quad: 15.02 .2018$

Kabul Tarihi $: 27.02 .2018$
\end{abstract}

\section{ABSTRACT}

Objective: The aim of this study, was to investigate the efficacy of four cavity disinfectant solutions and two different types of laser on the micro-shear bond strength of dentin adhesives as invitro.

Methods: Seventy permanent human molar teeth were sectioned parallel to the occlusal surface to expose dentin in the midcoronal. The specimens were randomly divided into seven main groups $(n=10)$ Then cavity disinfection procedures were applied; Saline(Control); Sodium Hypochlorite (NaOCl); Chlorhexidine Gluconate (CHX); Super-oxidized water (SPO); Aqueous ozone (AO); KTP laser; Er:YAG laser. Then the main groups were randomly divided into two subgroups as self-etch (Clearfil $\mathrm{S}^{3}$ Bond Plus) and etch-and-rinse (Bisco All-Bond Universal) adhesive systems. Four cylinders of composite resin were applied to each bonded dentin surface using a tygon tube. The specimens were tested with universal testing machine. The results were analyzed by two-way ANOVA and Tukey's tests.

Results: Statistical comparisons of the groups could be listed respectively from lowest to highest as; self-etch adhesive system, $\mathrm{CHX}<\mathrm{Control}$, AO,SPO $<\mathrm{KTP}<\mathrm{NaOCl}<\mathrm{Er}$ :YAG ( $<<0.05)$; etchand-rinse adhesive system, $\mathrm{CHX}<\mathrm{Control}=\mathrm{AO}=\mathrm{SPO}<\mathrm{KTP}<$ Er:YAG $<\mathrm{NaOCl} \quad(\mathrm{p}<0.05)$. When adhesive systems were compared with each other; there were found statistically significant differences within $\mathrm{NaOCl}$ groups, KTP laser groups and Er:YAG laser groups.

Conclusions: Er:YAG and KTP laser systems may increase the bond strength of both adhesive systems compared to CHX, SPO and AO. Therefore, both of laser systems may advisable for cavity disinfection in restorative dentistry.

Key Words: Aqueous ozone, cavity disinfection, chlorhexidine gluconate, laser, superoxidized water
Öz

Amaç: Bu çalışmanın amacı, dört farklı dezenfektan solüsyonu ve iki farklı lazer sisteminin, self-etch ve etch-and-rinse adeziv sistemlerin mikro-makaslama bağlanma dayanımı üzerine etkinliğinin in-vitro olarak araştırılmasıdır.

Materyal ve Metotlar: Bu çalışmada, 70 daimi insan molar dişin orta-kronal dentin yüzeyini açığa çıkaracak şekilde, oklüzal yüzeye paralel su soğutması altında, düşük hızlı elmas disk ile kesildi. Örnekler rastgele olarak 7 ana grubuna ayrıldı $(n=10)$ ve sonrasında kavite dezenfeksiyon işlemleri uygulandı. Grup 1, Serum Fizyolojik (Kontrol Grubu); Grup 2, Sodyum Hipoklorit (NaOCl); Grup 3, Klorheksidin Glukonat (CHX); Grup 4, Süperokside su (SPO); Grup 5, Ozonlu su (OS); Grup 6, KTP Lazer; Grup 7, Er:YAG Lazer. Sonra ana gruplar self-etch (Clearfil S3 Bond Plus) ve etch-and-rinse (Bisco All-Bond Universal) adeziv sistem olarak iki alt gruba ayrıldı. Dört adet kompozit rezin (Cavex Quadrant Universal LC) silindiri, tygon tüpleri kullanılarak bondlanmış dentin yüzeyine uygulandı. Örnekler mikro-makaslama modunda üniversal test cihazında test edildi. Sonuçlar iki yönlü varyans analizi ve Tukey testi ile değerlendirildi.

Bulgular: Araştırmadan elde edilen sonuçlara göre, self-etch adeziv grupları en düşükten en yükseğe doğru sırasıyla şu şekilde siralanabilir; $\mathrm{CHX}<$ Kontrol, OS, $\mathrm{SPO}<\mathrm{KTP}<\mathrm{NaOCl}<\mathrm{Er}: \mathrm{YAG}$ $(\mathrm{p}<0,05)$. Ayrıca, etch-and-rinse adeziv grupları istatistiksel olarak en düşükten en yükseğe doğru şu şekilde sıralanabilir; $\mathrm{CHX}<$ Kontrol,OS, SPO<KTP<Er:YAG<NaOCl $(\mathrm{p}<0,05)$. Her iki adeziv sistemde de, kontol, OS ve SPO grupları arasındaki farklar istatistiksel olarak önemsiz bulunmuştur $(\mathrm{p}>0,05)$. Adeziv sistemlere birbirleri ile karşılaştırıldığında; $\mathrm{NaOCl}$ gruplarının, KTP lazer ve gruplarının ve Er:YAG lazer gruplarının kendi aralarındaki farkları istatistiksel olarak anlamlı bulundu $(\mathrm{p}<0,05)$. Sonuçlar: Er:YAG ve KTP lazer sistemleri, CHX, SPO ve OS ile karşılaştırıldığında her iki sistemde bağlanma dayanımını artırabilir. $\mathrm{Bu}$ nedenle, restoratif diş hekimliğinde kavite dezenfeksiyonu için her iki lazer sistem de önerilebilir.

Anahtar Kelimeler: Kavite dezenfeksiyonu, klorheksidin glukonat, lazer, ozonlu su, süper-okside su 


\section{INTRODUCTION}

In restorative dentistry, the presence of bacteria has played an important role for success of treatment. Generally, restoration procedures aimed to remove infected dentin and to create suitable cavity for placing the restorative materials. The cariogenic microorganisms should be removed from cavity wall, smear layer and dentin tubules before starting the restorative treatment. Residual bacteria can cause pulpal sensitivity, inflamation and secondary caries. ${ }^{1}$ The survival of cariogenic microorganisms under restorative materials more than a year was demonstrated by Sharma et. al. ${ }^{2}$

Generally, cavity disinfection is an acceptable approach that may prevent residual potential risk of microorganism on tooth structures. ${ }^{3}$ There are varieties of commercial products in dental market for cavity disinfections. For example; chlorhexidine $(\mathrm{CHX})^{4,5}$, sodium hypochlorid $(\mathrm{NaOCl})^{6,7}$, aqueous ozone ${ }^{8}$, superoxidized water ${ }^{9-12}$ and lasers. ${ }^{13}$

CHX is one of the most commanly used cavity disinfectant solutions that is broadspectrum antibacterial agent. ${ }^{4}$ Its cationic structure provides to bind negative-charged bacteria cell, hydroxyapatite and oral mucosa. Concentration of CHX may show a bacteriostatic or bactericidal action on bacterial cell membrane. Moreover, it may alter the property of the dentinal surface. CHX allows rewetting of the dentin surface. Although CHX disinfection may not remove the smear layer throughout dentin surface, it may modify its appearance by removing loose smear debris. ${ }^{5}$

$\mathrm{NaOCl}$ is commonly used as endodontic irrigan that is an effective solution for reducing bacteria quantity on the dentin. Besides, it is preferred due to its antiseptic effect, wettability characteristic, non-specific proteolytic agent degradation of organic dentin. It is used mostly as irrigation and cavity disinfection solution. ${ }^{6}$ $\mathrm{NaOCl}$ is used with the aim of deproteinizing agent on dentin, improving adhesive wettability. Besides, deproteinization allows to a hydrophilic surface and porous structure. So $\mathrm{NaOCl}$ leads well mechanical retation. ${ }^{7}$

Ozone $\left(\mathrm{O}_{3}\right)$ is a powerful oxidizing agent that gain popularity for disinfection used to eliminate bacteria. Furthermore, it has two phases as gaseous and aqueous of ozone and has many industrial applications related to oxidation. It provides some advantages for elimination of bacteria in dentistry. Aqueous ozone (AO) may destruct cell walls and cytoplasmic membranes. Thus membrane permeability is increased and microorganisms are destroyed. ${ }^{8}$ Ozone is an anti-microbial (bactericidal, virucidal ve fungicidal), hemostatic and analgesic agent.

Recently, super-oxidized water (SPO) has been launched as disinfection for instruments and hard surface. SPO is a liquid biocide made by electrolysis of a dilute saline solution within a proprietary electrochemical cell. ${ }^{9}$ SPO includes the highly reactive super-oxide ion $\mathrm{O}_{2}$. These superoxide radicals can attack susceptible biological targets, including lipids, proteins and nucleic acids. ${ }^{10}$ Also, SPO produces effectively antimicrobial activity against a wide range of microorganisms. It is non-toxic, non-irritation, non-corrosive and a powerful oxidizer. ${ }^{11}$ The active ingredient of SPO is hypochlorous acid $(\mathrm{HOCl}) . \mathrm{HOCl}$ is considered as a powerful oxidizer and deproteinizer. ${ }^{12}$

In last years, various laser types have been frequently used in restorative dentistry. Moreover, the Er:YAG, KTP, Diode and Nd:YAG lasers are most commonly preferred for cavity disinfection. ${ }^{13}$ Er:YAG laser that is infrared light and strongly absorbed by water, is typically emit light with a wavelength of 2940 $\mathrm{nm}$. KTP (potassium-titanyl-phosphate) laser is a type with similar characteristics of Nd: YAG laser. However, its wavelength is halved of wavelength of $\mathrm{Nd}$ :YAG laser. It is primarily used for tooth bleaching process and some dental applications including dentin hypersensitivity, root canal disinfection and soft tissue surgery like Nd:YAG laser. ${ }^{14}{ }^{15}$ Lasers 
may reduce amount of bacteria by showing photothermal disinfection effect in dentin. ${ }^{16}$

Numerous cavity disinfectants have been recommended for clinical use. However, the effect of bond strength for cavity disinfectants has been a controversial issue. Some authors reported that disinfection procedures reduced the bond strength. ${ }^{2,5}$ On the other hand other researchers indicated that these procedures may not diminish the bond strength. ${ }^{3}$

The aim of this study was to investigate the efficacy of two conventional ( $\mathrm{CHX}$ and $\mathrm{NaOCl})$ and two recent disinfection solutions (AO and SPO) and two different types of laser (Er:YAG and KTP) on the micro-shear bond strength ( $\mu \mathrm{SBS})$ of dentin adhesives as in-vitro.

\section{MATERIALS AND METHODS}

\section{Specimen preparation:}

Seventy caries-free human permanent mandibular molars extracted for periodontal and orthodontic reasons were used in this study. Informed consent was obtained from the patients before the study, and the study was approved by the Local Ethics Committee on Human Research of Cumhuriyet University (2014-07/06).

The teeth were cleaned of peridontal soft tissue and calculus with a periodontal scaler and pumice. Later, the teeth have stored in distilled water in room temperature for 10 minutes prior to the study. The teeth were sectioned one of third crown to expose mid-coronal dentin with a lowspeed diamond disk saw (Isomet, Buehler Ltd., Lake Bluff IL, USA) under water coolant. Then, the teeth were embedded in autopolymerizing acrylic resin (Pan Acryl, Arma Dental, Istanbul, TURKEY) in prepared special cylinder mold (diameter: $2 \mathrm{~cm}$, high: $3 \mathrm{~cm}$ ). Dentin surfaces were smoothed using respectively 600, 800, 1000 and 1200 grit SiC paper (Buehler-Met II Silicon carbide grinding paper P400/600, IL, USA) under water coolant for 60 s to standardized the smear layer. Before performing the cavity disinfections, the teeth were sterilized in an autoclave (Melag,
Euroklav 23V-S, Berlin, GERMANY) for $20 \mathrm{~min}$ each at $121^{\circ} \mathrm{C}$.

\section{Control and experimental groups}

The teeth were randomly divided into one control and 6 experimental groups of 10 teeth each. Cavity disinfectant materials manufacturer and active ingredient are presented in Table 1.

Table 1. Active ingredient and manufacturer of cavity disinfectants used in the study.

\begin{tabular}{|c|c|c|}
\hline Product & Active ingredient & Manufacturer \\
\hline Saline & $0.9 \% \mathrm{NaCl}$ & Izotonik, Turkey \\
\hline $\mathrm{NaOCl}$ & $5.25 \%$ Sodium hypochloride & Clorox Co, Egypt \\
\hline$\overline{C H X}$ & $2 \%$ Chlorhexidine gluconate & Troy, Turkey \\
\hline SPO & $50-80 \mathrm{mg} / \mathrm{L}$ hypochlorous acid & Medilox, Turkey \\
\hline Aqueous Ozone & 8 ppm aqueous ozone & TeknO $_{3}$ zone, Turkey \\
\hline KTP Laser & $\begin{array}{l}\text { Power density: } 1.5 \mathrm{~W} / \mathrm{cm}^{2} \\
\text { Wavelength: } 532 \mathrm{~nm} \\
\text { Repeated pulsed mode } \\
(\text { Ton } 20 \mu \mathrm{s} \text { s, Toff } 30 \mu \mathrm{s} \text { ) }\end{array}$ & Smartlite D, Italy \\
\hline Er:YAG Laser & $\begin{array}{c}\text { Power density: } 1.5 \mathrm{~W} / \mathrm{cm}^{2} \\
\text { Wavelength: } 2940 \mathrm{~nm} \\
\text { Continuous mode } \\
(15 \mathrm{~Hz}, 100 \mathrm{~mJ}, 700 \mu \mathrm{s})\end{array}$ & Smart 2940D, Italy \\
\hline
\end{tabular}

Saline (Control group): Dentin surface was disinfected with $0.9 \%$ saline solution with $10 \mathrm{~mL} / \mathrm{min}$ flow rate for $60 \mathrm{~s}$,

Sodium Hypochloride ( $\mathrm{NaOCl}$ ): Dentin surface was disinfected with $5.25 \% \mathrm{NaOCl}$ solution with $10 \mathrm{~mL} / \mathrm{min}$ flow rate for $60 \mathrm{~s}$,

Chlorhexidine Glukonat (CHX): Dentin surface was disinfected with 2\% CHX (Troy, Ankara, Turkey) solution with $10 \mathrm{~mL} / \mathrm{min}$ flow rate for $60 \mathrm{~s}$,

Super-oxidized water (SPO): SPO (Medilox; OM Medical Dental Textile, Ankara, TURKEY) that consists of a mixture of oxidizing substances including hypochlorous acid at a concentration of $50-80 \mathrm{mg} / \mathrm{L}$, with a $\mathrm{pH}$ of 5.5 and a redox potential $>850-1000 \mathrm{mV}$. Dentin surface was disinfected with SPO with $10 \mathrm{~mL} / \mathrm{min}$ flow rate for $60 \mathrm{~s}$,

Aqueous Ozone (AO): By the ozone generator specially created by $\mathrm{TeknO}{ }_{3}$ zone $\left(\mathrm{TeknO}_{3}\right.$ zone, Izmir, TURKEY) aqueous ozone was produced. The amount of ozone in the water was scaled with help of the probe that was in the reaction tank connected to the generator. The ozone 
density of distilled water was monitored via the digital indicator on the generator. Dentin surface was disinfected with $8 \mathrm{ppm}$ AO with $10 \mathrm{~mL} / \mathrm{min}$ flow for $60 \mathrm{~s}$,

KTP Laser: Dentin surfaces were irradiated with KTP laser (Smartlite D; DEKA M.E.L.A. Srl Calenzano, ITALY) which is output power of $1.5 \mathrm{~W}$ and wavelength of $532 \mathrm{~nm}$. In the course of laser treatment, the fiber tip (diameter of $200 \mu \mathrm{m}$ ) was applied with a non-contact mode and repeated pulsed mode (Ton $20 \mu \mathrm{s}$, Toff $30 \mu \mathrm{s}$ ) for $60 \mathrm{~s}$,

Er:YAG Laser: Dentin surfaces were irradiated with an Er:YAG laser (Smart 2940D, DEKA M.E.L.A. SRL, Calenzano, ITALY) emitting pulsed infrared radiation at a wavelength of $2940 \mathrm{~nm}$. We preferred frequency range of 15 $\mathrm{Hz}$, energy density of $100 \mathrm{~mJ}$ and pulse duration is fixed at $700 \mu \mathrm{s}$. So it was performed power density was $1.5 \mathrm{~W} / \mathrm{cm}^{2}$. Handpiece of the laser was applied from the 1-2 mm distance and on focused mode. Dentin surfaces were irradiated in a sweeping fashion with a water flow of 10 $\mathrm{mL} / \mathrm{min}$ for $60 \mathrm{~s}$ by the Er:YAG laser.

\section{Adhesive Procedures}

Each group was randomly divided into two subgroups according to adhesive systems employed $(\mathrm{n}=5)$. Clearfil S3 Bond Plus (Kuraray, Osaka, JAPAN) and All Bond Universal (Bisco, Schaumburg, IL, USA) adhesive systems is summarized in Table 2.

Table 2. Adhesive systems used in the study.

\begin{tabular}{|c|c|c|c|}
\hline Adhesive System & Manufacturer & Composition & Manufacturer recommendations \\
\hline $\begin{array}{l}\text { All Bond Universal } \\
\text { Etch-and-Rinse } \\
\text { Adhesive System } \\
\end{array}$ & $\begin{array}{l}\text { ABU, Bisco, Inc, } \\
\text { ABD }\end{array}$ & $\begin{array}{l}\text { MDP, Bis-GMA, HEMA, } \\
\text { ethanol, water, initiators }\end{array}$ & $\begin{array}{l}\text { 1. Apply two separate coats of adhesive } \\
\text { 2. Evaporate excess solvent by } \\
\text { thoroughly air-drying for } 10 \mathrm{~s} \text {. } \\
\text { 3. Light cure for } 10 \mathrm{~s} \\
\end{array}$ \\
\hline $\begin{array}{l}\text { Clearfil S }{ }^{3} \text { Bond Plus } \\
\text { Self-Etch Adhesive } \\
\text { System }\end{array}$ & $\begin{array}{l}\text { Kuraray Medical } \\
\text { Inc, JAPONYA }\end{array}$ & $\begin{array}{l}\text { MDP, Bis-GMA, HEMA, } \\
\text { Hydrophobic } \\
\text { dimethacrylate, dl- } \\
\text { camphoroquinone, thyl } \\
\text { alcohol, water,silanated } \\
\text { colloidal silica }\end{array}$ & $\begin{array}{l}\text { 1. Apply BOND and leave for } 10 \mathrm{~s} \text {. } \\
\text { 2. Dry with mild air for more than } 5 \mathrm{~s} \text {. } \\
\text { 3. Light cure for } 10 \mathrm{~s} \text {. }\end{array}$ \\
\hline
\end{tabular}

Self-etch adhesive procedures: Clearfil $\mathrm{S}^{3}$ Bond Plus was applied bonding agent to the dentin surface. After it was left in place for 10s, dentin surface was dried by blowing mild air for more than $5 \mathrm{~s}$.
Etch-and-rinse adhesive procedure: All-Bond Universal has stated that it has suitable for both the self-etch and etch-and-rinse approach. So ABU was applied for the etch-and-rinse bonding mode. Dentin surface was etch with $35 \%$ phosphoric acid gel Select $\mathrm{HV}^{\circledR}$ Etch (Bisco, Schaumburg, IL, USA) for 15s, wash for $30 \mathrm{~s}$ with water spray and dried with mold air. Then, All-Bond Universal bonding agent was applied two separate coats to entire dentin. Bonding agent was evaporated excess solvent by thoroughly air-drying for at least 10s.

\section{Prepared of composite resin cylinders}

Before polymerization of the dentin bonding, four number Tygon tubing (Tygon, Norton Performance Plastic Co, Cleveland, OH, USA) which is internal diameter of $0.8 \mathrm{~mm}$ and height of $0.5 \mathrm{~mm}$ placed on the bonded dentin surface. Then, power of $1000 \mathrm{~mW} / \mathrm{cm}^{2}$ of LED light curing (VALO Ultradent, Utah, USA) was performed in order to fix the tygon tubing. Resin composite (Quadrant Universal-LC, Cavex, Haarlem, Holland), shade of A2, was packed into tygon tubing and then it was cured by LED light curing unit for 20s (Fig. 1a). Tygon tubes were cut gently by scalpel after one hour storage at room temperature. Thus, four cylinders of resin composite were obtained on bonded dentin surface (Fig. 1b).

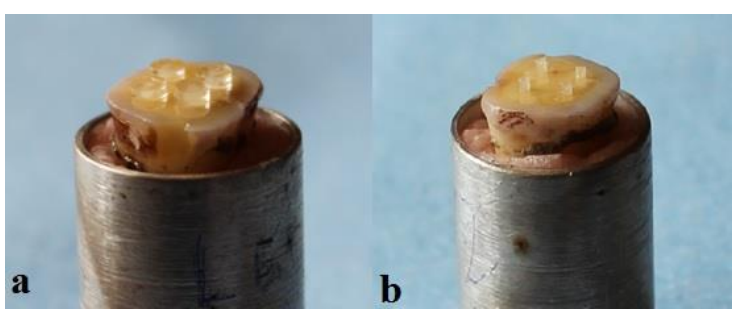

Figure 1. a) Composite resin is placed in tygon tubing b) Four composite cyclinder on dentin surface

\section{Micro-shear bond strength test}

The restorated teeth were storaged in distilled water for $24 \mathrm{~h}$ before measured with a universal test machine (LF Plus, Lloyd, Instrument, Ametek Inc, ENGLAND). Restorated teeth were fixed on universal testing machine's apparatus and micro-shear bond strength $(\mu-$ 
SBS) test was measured at a crosshead speed $0.5 \mathrm{~mm} / \mathrm{min}$. A thin wire (diameter $0.2 \mathrm{~mm}$ ) was looped around the composite cylinder in order to bond strenght. The fracture load $(\mathrm{N})$ was recorded and the micro-shear bond strength was calculated as MPa.

\section{Statistical Analysis}

Data of the bond strengths were analyzed using the SPSS statistical software program (version 22.0, SPSS Inc., Chicago, USA). A two way ANOVA and Tukey's Test was executed for measured significant differences of the groups with the significance level set at 0.05 .

\section{RESULTS}

The mean and standard deviations of $\mu$-SBS for each adhesive systems and each groups are presented in Table 3.

Table 3. Mean and standars deviations micro-shear bond strength of study groups and statistical comparisons (two way ANOVA, Tukey's test).

\begin{tabular}{c|c|c}
\hline \hline $\begin{array}{c}\text { Groups } \\
n=10\end{array}$ & $\begin{array}{c}\text { Self-Etch Adhesive System } \\
\text { (mean } \pm \mathrm{SD})\end{array}$ & $\begin{array}{c}\text { Etch-and-Rinse Adhesive System } \\
\text { (mean } \pm \mathrm{SD})\end{array}$ \\
\hline $\begin{array}{c}\text { Group 1 } \\
\text { Control }\end{array}$ & $12,15 \pm 1,36^{\mathrm{a}}$ & $13,18 \pm 2,13^{\mathrm{b}}$ \\
\hline $\begin{array}{c}\text { Group 2 } \\
\text { NaOCl }\end{array}$ & $16,37 \pm 1,86^{\mathrm{A}}$ & $24,22 \pm 1,75^{\mathrm{A}}$ \\
\hline $\begin{array}{c}\text { Group 3 } \\
\text { CHX }\end{array}$ & $9,34 \pm 0,89$ & $10,29 \pm 1,07$ \\
\hline $\begin{array}{c}\text { Group 4 } \\
\text { SPO }\end{array}$ & $12,48 \pm 1,01^{\mathrm{a}}$ & $13,38 \pm 2,02^{\mathrm{b}}$ \\
\hline $\begin{array}{c}\text { Group 5 } \\
\text { Aqueous Ozone }\end{array}$ & $12,43 \pm 1,96^{\mathrm{a}}$ & $13,29 \pm 1,07^{\mathrm{b}}$ \\
\hline $\begin{array}{c}\text { Group 6 } \\
\text { KTP Laser }\end{array}$ & $14,37 \pm 1,10^{\mathrm{B}}$ & $16,44 \pm 1,86^{\mathrm{B}}$ \\
\hline $\begin{array}{c}\text { Group 7 } \\
\text { Er:YAG Laser }\end{array}$ & $18,44 \pm 2,14^{\mathrm{c}}$ & $20,59 \pm 2,27^{\mathrm{c}}$ \\
\hline \hline By the tWO-Way ANO & \\
\hline \hline
\end{tabular}

By the two-way ANOVA: $\mathrm{F}=118.102, \mathrm{P}=0.000 ;(\mathrm{P}<0.05) ; \mathrm{n}=10$ $\mathrm{A}, \mathrm{B}, \mathrm{C}$ Values with same and capital superscript letter in line were statistically different at $\mathrm{p}<0.05$.

$\mathrm{a}, \mathrm{b}$ Values with same and small superscript letter in vertical columns were not statistically different at $\mathrm{p}<0.05$.

Statistical comparisons of the self-etch adhesive system groups could be listed respectively from lowest to highest as; $\mathrm{CHX}<$ Control $=\mathrm{AO}=\mathrm{SPO}<\mathrm{KTP}<\mathrm{NaOCl}<\mathrm{Er}: \mathrm{YAG}$ $(p<0.05)$. When bond strenghts of the groups were compared each other in self-etch adhesive system, CHX solution group was significantly the lowest, Er:YAG laser group was significantly the highest among the other groups $(\mathrm{p}<0.05)$. There were no significantly differences among control, AO and SPO groups ( $\mathrm{p}>0.05)$.

Moreover, etch-and-rinse adhesive groups could be respectively sorted from lowest to highest as; $\mathrm{CHX}<\mathrm{Control}=\mathrm{AO}=\mathrm{SPO}<\mathrm{KTP}<$ Er:YAG $<\mathrm{NaOCl}(\mathrm{p}<0.05)$. When bond strength of treated $\mathrm{CHX}$ solution was significantly lowest, $\mathrm{NaOCl}$ solution was significantly higher than other groups in etch-and-rinse adhesive system $(p<0.05)$. There were no statistically significantly differences among control, AO and SPO groups $(\mathrm{p}>0.05)$.

When the adhesive systems were compared with each other, statistically significant differences were found among $\mathrm{NaOCl}, \quad \mathrm{KTP}$ and Er:YAG laser groups $(\mathrm{p}<0.05)$, There were no found statistically significant differences among other groups ( $>0.05)$.

\section{DISCUSSION}

In present study, although CHX solution decreased the $\mu \mathrm{SBS}, \mathrm{NaOCl}$ solution, Er:YAG and KTP laser increased the $\mu$ SBS. Moreover, SPO and AO solutions had no adverse effect to the $\mu$ SBS with both adhesive systems.

In clinical practice of dentistry, bacteria may remain in smear layer and dentin tubules during cavity preparation. For this reason, an antibacterial solution should be applied on dentin surface to reduce the potential risks for residual bacteria. ${ }^{3}$ While cavity disinfectants reduce bacteria amount and its potential risks, they may affect the bond strength of dentincomposite resin. Optimal cavity disinfectants should have antimicrobial effect and no adverse effect to the bond strength of adhesive systems.

$\mathrm{NaOCl}$ solution is well-known antibacterial effect and commonly used cavity disinfectant. Due to its effective oxidizing and deproteinizing properties, $\mathrm{NaOCl}$ pretreatment partially removes dentin's organic structure and smear layer. ${ }^{12}$ These may be beneficial for adhesive systems performance. Phrukkanon $e t$ $a l .{ }^{17}$ reported that pretreatment dentin surface 
with $12.5 \% \mathrm{NaOCl}$ for $60 \mathrm{~s}$ increased the bond strength of the etch-and-rinse adhesive system. Moreover Arias et al. ${ }^{18}$ reported that $10 \%$ $\mathrm{NaOCl}$ enhanced the bond strenght of etch-andrinse adhesive system. In contrast to the other studies, Elkassas et al. ${ }^{3}$ reported that $5.25 \%$ $\mathrm{NaOCl}$ was decreased the bond strenght of the etch-and-rinse adhesive system, whereas increased the bond strenght of the self-etch adhesive system. In the present study, $\mathrm{NaOCl}$ solution group increased the bond strength of both adhesive systems. Although the results are in agreement with the result of some studies ${ }^{17}$, ${ }^{18}$, the results are in contrary with Elkassas et $a l .{ }^{3}$ The reason why these results are different from ours is about depending on the testing different of tooth surface, test methodology and etch of application time. Whereas, $\mathrm{NaOCl}$ solution can remove the exposed collagen fibrils and smear layer on dentin surface. This surface which richer hydroxyapatite crytals increased the bonding of the adhesive systems. ${ }^{3}$

CHX is utilized in clinical due to broad spectrum antibacterial agent. CHX is preferred because of its low toxicity, affinity of negative surface as cell wall and extracellular polysaccharide. ${ }^{4} \mathrm{CHX}$ solution has been used as cavity disinfection due to its well property on dentin until last years. However, the effect of chlorhexidine adhesive systems of bond strength to dentin is controversial issue. Some studies $^{2,19,20}$ reported that pretreatment of dentin surface of $2 \% \mathrm{CHX}$ for 20 s affected adversely the bond strength of self-etch adhesive system. The other study, Gurgan et $a l .{ }^{21}$ expressed that pretreatment of $\mathrm{CHX}$ before or after acid etching dentin surface decreased the bond strenght of etch-and-rinse adhesive systems. Sharma et al. ${ }^{2}$ reported that dentinal tubules were not clearly observed in SEM micrography when dentin surface treated CHX solution. On the other hand, a few studies ${ }^{3,22}$ showed that CHX (2\%) pretreatment increased the bond strenght of self-etch adhesive system. In the present study, CHX pretreatment decreased the bond strenght of both adhesive systems. This result is compatible with above study $^{2,19-21}$ results. In contrast to the above study, few studies ${ }^{3,} 22$ reported that CHX increased the bond strenght of adhesives. These results are different from present study because of deciduous teeth dentin, difference of adhesive ingredients, different layer regularizations and the short disinfection duration.

Recently, SPO has been produced as a new disinfectant agent for cleaning hard surfaces. SPO has been recommended as a therapeutic agent due to the treatment of periodontitits. ${ }^{23} \mathrm{In}$ available literature, there have been mostly microbiological study regarding SPO. RossiFedele et al..$^{24}$ reported that $\mathrm{NaOCl}$ significantly better killer E. faecalis than SPO solution but SPO solution has also significantly antimicrobial action. In the present study the SPO for cavity disinfectant was preferred due to its antibacterial effectiveness. However, there have been a few published researches about the pretreatment effect of SPO on the bond strength and alteration of dentin surface. The active ingredient of SPO is hypochlorous acid $(\mathrm{HOCl}) .{ }^{11}$ One of the studies on this subject, Kunawarote et al. ${ }^{12}$ reported that different concentration and application time of $\mathrm{HOCl}$ solutions had no adverse effect of the bond strenght of self-etch adhesive system. Another study, Kunawarote et al. ${ }^{25}$ showed in SEM study that stabilized $\mathrm{HOCl}$ solution dissolved the superficial collagen in the carries-affected dentin. In present study, SPO had no adverse effect on the bond strenght of both adhesive systems. These results are agreement with study by Kunawarote et al. ${ }^{12}$

Ozone has been suggested in dentistry due to its antibacterial, disinfectant and healing properties. It may be applied for treatment of early carious lesions, disinfection of cavity, root canals and periodontal pockets. ${ }^{8}$ Ozone is extremely effective against Gram (+) and Gram (-) bacteria which cause carious lesion. In dentistry, ozone can be used aqueous and 
gaseous ozone forms. In literature, few studies have the effect of aqueous ozone on bond strenght. At one of this studies, Oznurhan et $a .^{22}$ found that aqueous ozone (3-4 ppm) increased bond strength of self-etch adhesive system. Pithon et al. ${ }^{26}$ found that ozonated water didn't alter bond strenght of brackets bonded with composite resin. Also ozone has not affected the sealing ability of adhesive systems. ${ }^{27-29}$ In present study, aqueous ozone did not affect bond strength of adhesive systems compared control groups as similar to the results of the study of Pithon et. al. ${ }^{26}$ On the contrary, Oznurhan et al. ${ }^{22}$ were found dissimilar results because of their study methods (lower ppm of aqueous ozone, different test method and deciduous teeth). Ozone may not change the physical properties of enamel and not affect the modulus of elasticity and vickers hardness of dentin. ${ }^{29}$

Dental lasers, named according to their wavelength, can be an effective way to carry out many dental procedures. Mostly used dental lasers are Nd:YAG (1064 nm), Er:YAG (2940 nm, Er,Cr:YSSG (2780 nm), Diode (780-980 $\mathrm{nm})$ and KTP (532 nm) lasers. Laser irradiation may be used for cleaning, disinfecting and removing smear layer on dentin surface. Moreover, laser may eliminate bacteria and prevent residual caries. ${ }^{13}$

Er:YAG laser irradiation may be highly absorbed by water molecules present in the crystalline tooth structure. The thermomechanical ablation of water within the tooth mineral substrate causes volume expantion and explode away surrounding tissue. ${ }^{30}$ Er:YAG laser irradiation may present irregular dentin surface during cavity preparation. Moreover, Aoki et al. ${ }^{31}$ showed in SEM observation that when laser applied to dentin surface, smear layer was removed and orifices of dentin tubules were exposed. As a result, these characteristics enhance bond strenght between an Er:YAG laser irradiated surface and adhesive resin. ${ }^{32}$ Güven et al. ${ }^{33}$ ve Ramos et al. ${ }^{34}$ reported that Er:YAG laser significantly enhanced SBS of self-etch adhesive. Celik et $a l .{ }^{13}$ reported that Er,Cr:YSGG laser increased bond strength of etch-and-rinse adhesive. In the present study, Er:YAG laser pretreatment improved the bond strenght of both adhesive systems. The results of this study are in parallel with the above study results. ${ }^{13,33}$

KTP laser, with a wavelength of $532 \mathrm{~nm}$, is frequency-doubled Nd: YAG laser and it emits a green visible radiation. Despite of the known antibacterial property of laser, few reports have been published on the effect of KTP laser regarding to the bond strength. Schoop et al. ${ }^{35}$ reported that $1 \mathrm{~W}$ output power of KTP laser cause major mophological changes and recrystallization of dentinal surface. When KTP laser irradiation was applicated hard tissues, it may provide to melt and recrystallisation. Thus, KTP laser irradiation of dentinal tubules may result in sealing of their orifices. ${ }^{35}$ Rolla et al. ${ }^{36}$ reported that $\mathrm{Nd}$ :YAG laser significantly increased bond strength of self-etch adhesive. In present study, KTP laser significantly increased $\mu$ SBS values than control, CHX, SPO and AO groups in the both adhesive systems. This result is compatible with Rolla et al..$^{36}$ study result.

\section{CONCLUSION}

Within the limitations of this study, Er:YAG and KTP laser systems may increase the bond strength of both adhesive systems compared to CHX, SPO and AO. Therefore, both of laser systems may advisable for cavity disinfection in restorative dentistry. In light of this study, while the application of self-etch adhesive system may be advised with Er:YAG laser irradition, etch-and-rinse adhesive system should be used with $\mathrm{NaOCl}$ solution in terms of cavity disinfection.

\section{Acknowledgment}

The study was financed by the Scientific Research Unit of Cumhuriyet University (CUBAP) in Sivas, Turkey. 


\section{Author Disclosure Statement}

None of the authors have any competing financial interests to disclose.

\section{REFERENCES}

1. Imazato $S$, Torii $Y$, Takatsuka $T$, Inoue $K$, Ebi N, Ebisu S. Bactericidal effect of dentin primer containing antibacterial monomer methacryloyloxydodecylpyridinium bromide (MDPB) against bacteria in human carious dentin. J Oral Rehabil 2001;28(4):314-9.

2. Sharma V, Rampal P, Kumar S. Shear bond strength of composite resin to dentin after application of cavity disinfectants - SEM study. Contemp Clin Dent 2011;2(3):155-9.

3. Elkassas DW, Fawzi EM, El Zohairy A. The effect of cavity disinfectants on the micro-shear bond strength of dentin adhesives. Eur J Dent 2014;8(2):184-90.

4. Varoni E, Tarce M, Lodi G, Carrassi A. Chlorhexidine (CHX) in dentistry: state of the art. Minerva Stomatol 2012;61(9):399-419.

5. Meiers JC, Kresin JC. Cavity disinfectants and dentin bonding. Oper Dent 1996;21(4):1539.

6. Mohammadi Z. Sodium hypochlorite in endodontics: an update review. Int Dent J 2008;58(6):329-41.

7. Perdigao J, Lopes M, Geraldeli S, Lopes GC, Garcia-Godoy F. Effect of a sodium hypochlorite gel on dentin bonding. Dent Mater 2000;16(5):311-23.

8. Kumar A, Bhagawati S, Tyagi P, Kumar P. Current interpretations and scientific rationale of the ozone usage in dentistry: A systematic review of literature. European Journal of General Dentistry 2014;3(3):175.

9. Tapper R, Smith J, Cocking C, Beech I. Atomic force microscopy study of the biocidal effect of super-oxidised water, Sterilox. 1998.

10.Cabiscol E, Tamarit J, Ros J. Oxidative stress in bacteria and protein damage by reactive oxygen species. Int Microbiol 2000;3(1):3-8.

11.Solovyeva AM, Dummer PM. Cleaning effectiveness of root canal irrigation with electrochemically activated anolyte and catholyte solutions: a pilot study. Int Endod J 2000;33(6):494-504.

12.Kunawarote $S$, Nakajima $M$, Shida $K$, Kitasako Y, Foxton RM, Tagami J. Effect of dentin pretreatment with mild acidic $\mathrm{HOCl}$ solution on microtensile bond strength and surface pH. J Dent 2010;38(3):261-8.

13. Celik C, Ozel Y, Bagis B, Erkut S. Effect of laser irradiation and cavity disinfectant application on the microtensile bond strength of different adhesive systems. Photomed Laser Surg 2010;28(2):267-72.

14.De Moor RJ, Vanderstricht $K$. The use of the KTP laser, an added value for tooth bleaching. Journal of Oral Laser Applications 2009;9(4):219.

15.Palaia G, Gaimari G, Giudice RL, Galanakis A, Tenore G, Romeo U. Excision of an oral angiolipoma by KTP laser: a case report. Ann Stomatol 2011;2(1-2):28-31.

16. Asnaashari M, Safavi N. Disinfection of Contaminated Canals by Different Laser Wavelengths, while Performing Root Canal Therapy. J Lasers Med Sci 2013;4(1):8-16.

17.Phrukkanon S, Burrow MF, Hartley PG, Tyas MJ. The influence of the modification of etched bovine dentin on bond strengths. Dent Mater 2000;16(4):255-65.

18. Arias VG, Bedran-de-Castro AK, Pimenta LA. Effects of sodium hypochlorite gel and sodium hypochlorite solution on dentin bond strength. J Biomed Mater Res B Appl Biomater 2005;72(2):339-44.

19.Ercan E, Erdemir A, Zorba YO, Eldeniz AU, Dalli M, Ince B, et al. Effect of different cavity disinfectants on shear bond strength of composite resin to dentin. J Adhes Dent 2009;11(5):343-6.

20.Reddy MS, Mahesh MC, Bhandary S, Pramod J, Shetty A, Prashanth MB. Evaluation of effect of different cavity disinfectants on shear bond strength of composite resin to dentin using two-step self-etch and one-step self-etch bonding systems: a comparative in vitro study. J Contemp Dent Pract 2013;14(2):275-80. 
21.Gurgan S, Bolay S, Kiremitci A. Effect of disinfectant application methods on the bond strength of composite to dentin. J Oral Rehabil 1999;26(10):836-40.

22. Oznurhan F, Ozturk C, Ekci ES. Effects of different cavity-disinfectants and potassium titanyl phosphate laser on microtensile bond strength to primary dentin. Niger J Clin Pract 2015;18(3):400-4.

23. Mainnemare A, Megarbane B, Soueidan A, Daniel A, Chapple IL. Hypochlorous acid and taurine-N-monochloramine in periodontal diseases. J Dent Res 2004;83(11):823-31.

24. Rossi-Fedele G, Figueiredo JA, Steier L, Canullo L, Steier G, Roberts AP. Evaluation of the antimicrobial effect of super-oxidized water (Sterilox $(\mathrm{R}))$ and sodium hypochlorite against Enterococcus faecalis in a bovine root canal model. J Appl Oral Sci 2010;18(5):498-502.

25. Kunawarote S, Nakajima M, Foxton RM, Tagami J. Effect of pretreatment with mildly acidic hypochlorous acid on adhesion to cariesaffected dentin using a self-etch adhesive. Eur J Oral Sci 2011;119(1):86-92.

26.Pithon MM, dos Santos RL. Does ozone water affect the bond strengths of orthodontic brackets? Aust Orthod J 2010;26(1):73-7.

27. Celiberti P, Pazera P, Lussi A. The impact of ozone treatment on enamel physical properties. Am J Dent 2006;19(1):67-72.

28.Schmidlin PR, Zimmermann J, Bindl A. Effect of ozone on enamel and dentin bond strength. J Adhes Dent 2005;7(1):29-32.

29.Magni E, Ferrari M, Hickel R, Huth KC, Ilie N. Effect of ozone gas application on the mechanical properties of dental adhesives bonded to dentin. Dent Mater 2008;24(10):1428-34.

30.Schein MT, Bocangel JS, Nogueira GE, Schein PA. SEM evaluation of the interaction pattern between dentin and resin after cavity preparation using ER:YAG laser. J Dent 2003;31(2):127-35.

31.Aoki A, Ishikawa I, Yamada T, Otsuki M, Watanabe H, Tagami J, et al. Comparison between Er:YAG laser and conventional technique for root caries treatment in vitro. $\mathrm{J}$ Dent Res 1998;77(6):1404-14.

32. Geraldo-Martins VR, Robles FR, Matos AB. Chlorhexidine's effect on sealing ability of composite restorations following Er:YAG laser cavity preparation. J Contemp Dent Pract 2007;8(5):26-33.

33. Guven Y, Aktoren O. Shear bond strength and ultrastructural interface analysis of different adhesive systems to Er:YAG laser-prepared dentin. Lasers Med Sci 2015;30(2):769-78.

34. Ramos TM, Ramos-Oliveira TM, de Freitas PM, Azambuja N, Jr., Esteves-Oliveira M, Gutknecht N, et al. Effects of Er:YAG and $\mathrm{Er}, \mathrm{Cr}$ :YSGG laser irradiation on the adhesion to eroded dentin. Lasers Med Sci 2015;30(1):17-26. 35.Schoop U, Kluger W, Dervisbegovic S, Goharkhay K, Wernisch J, Georgopoulos A, et al. Innovative wavelengths in endodontic treatment. Lasers Surg Med 2006;38(6):624-30. 36. Rolla JN, Mota EG, Oshima HM, Junior LH, Spohr AM. Nd:YAG laser influence on microtensile bond strength of different adhesive systems for human dentin. Photomed Laser Surg 2006;24(6):730-4.

\section{Corresponding Author}

Ihsan HUBBEZOGLU (DDS. PhD. Professor)

Department of Restorative Dentistry

Faculty of Dentistry

Cumhuriyet University, Sivas, Turkey

Tel: +90 346 2191010- 2792

Mobile tel: +90 5428160044

Fax: +90 3462191237

E-mail: hubbezoglu@gmail.com 